\title{
Th.G. Sahama's (1910-1983) volcanological and mineralogical studies in Africa: Part II. Minerals of granitic pegmatites and other mineral occurrences of eastern and southern Africa
}

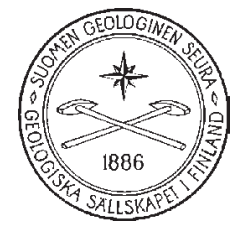

\author{
ILMARI HAAPALA \\ Department of Geosciences and Geography, P.O. Box 64, FI-00014 University of Helsinki, \\ Finland
}

\begin{abstract}
Absract
Eight mineralogical expeditions during 1961-1974 to pegmatites and other mineral occurrences of eastern and southern Africa produced abundant research material. Dr. 0. v. Knorring from University of Leeds, U.K., participated in some expeditions, and Professors J.M. Correia Neves and J.E. Lopes Nunes participated in the study the granite pegmatites of Zambezia, northeastern Mozambique, where in the 1960's and 1970's were active mining operations. From the Zambezian pegmatites, Sahama and his coworkers and assistants published studies on the Ta-Nb minerals (tantalite-columbite, wodginite, ixiolite, niobian wolframite, niobian rutile) as well as the bismuth and antimony minerals, including a new mineral, "natural monoclinic bismuth vanadate"(later named clinobisvanite). As a result of a systematic research, based on geochemical deductions, a new mineral, hafnon, was found as the high hafnium member of the isomorphic zircon-hafnon series. From the Buranga pegmatite in Rwanda, several phosphate minerals, including a new mineral species, burangaite, were described. In connection with the mineralogical research of the tungsten deposits of Uganda and Rwanda, two new secondary tungsten minerals, mpororoite and cerotungstite, were found. From Madagascar, Sahama collected material for mineralogical studies of sapphirine and kornerupine, and from Namibia, a new mineral species, namibite, was described.
\end{abstract}

Corresponding author email: ilmari.haapala@helsinki.fi

\section{Introduction}

Professor Th.G. Sahama's expeditions to the Virunga Volcanic Field and petrological-mineralogical studies on the Nyiragongo volcano were described by Haapala (2011). While these expeditions and studies still continued in the 1960's, Sahama also made other expeditions to different parts of Africa to study other exotic rocks and mineral occurrences, especially pegmatites. This article deals with his mineralogical studies of rare-mineral pegmatites and hydrothermal deposits throughout East, Central and southern Africa (Table 1).

All the intercontinental and long distance tra- 
Table 1. Dates and main topics of Sahama's expeditions during 1961-1974.

\begin{tabular}{|c|c|}
\hline Date & Main research topics \\
\hline 1961, July 11-October 1. & $\begin{array}{l}\text { (1) The carbonatites and related alkaline rocks of Uganda, Tanzania, } \\
\text { Mosambique, and South Africa, and (2) the pegmatites of Rwanda and } \\
\text { Mozambique. Dr. O. v. Knorring participated in the trip to South Africa } \\
\text { and Mozambique. }\end{array}$ \\
\hline 1963, June 3-July 25. & $\begin{array}{l}\text { (1) The alluvial tin deposits and pegmatites of Nigeria (with Dr. D.C. Tur- } \\
\text { ner), (2) the Logonjo and Bailunda carbonatites in Angola with geologists } \\
\text { from the Geological Survey of Angola, (3) the Geological Survey of Mo- } \\
\text { zambique in Lourenço Marques (Maputo) and the pegmatites of Zambe- } \\
\text { zia, and (4) the Mineral Research Division, Geological Survey of Tanza- } \\
\text { nia, based in Dodoma. }\end{array}$ \\
\hline 1966, June 20-July 30. & $\begin{array}{l}\text { (1) The Geological Survey and the University of Lourenço Marques, (2) } \\
\text { the Zambezian pegmatites, and (3) the Karibib pegmatites in Namibia. }\end{array}$ \\
\hline 1967, September 9-October 14/24. & $\begin{array}{l}\text { (1) The pegmatites and tungsten-tin mines of southern Uganda, (2) } \\
\text { Madagascar. Dr. O. v. Knorring participated in the travels. }\end{array}$ \\
\hline 1969, August 3-September 16. & $\begin{array}{l}\text { (1) The Ethipian Rift Valley and (2) the pegmatites and tungsten-tin veins } \\
\text { of southwestern Uganda and northern Rwanda, with Dr. O. v. Knorring } \\
\text { and Mr. R. Alviola. }\end{array}$ \\
\hline 1972, August 2-6. & $\begin{array}{l}\text { Sahama traveled by air through Entebbe to Goma, the Congo. He } \\
\text { participated in an excursion to Mt. Nyiragongo and probably visited the } \\
\text { Zambezian pegmatites. Details of this expedition are not available. }\end{array}$ \\
\hline 1973, July 10 - August 24. & $\begin{array}{l}\text { (1) Guest lectures and mineralogical research together with Professors } \\
\text { J.M. Correia Neves and J.E. Lopes Nunes at the University of Lourenço } \\
\text { Marques and (2) the Zambezian pegmatites. }\end{array}$ \\
\hline 1974, June 15-July 27. & $\begin{array}{l}\text { (1) Research collaboration with Professors J.E. Lopes Nunes and J.M. } \\
\text { Correia Neves at the University of Lourenço Marques and (2) the } \\
\text { Zambezian pegmatites. }\end{array}$ \\
\hline
\end{tabular}

vels in Africa were now made by air, local trips by cars provided by the Geological Surveys and Universities, or by hired taxis. Sahama continued his practical custom to keep in contact at the beginning or ending of his expeditions with European research centres (e.g., London, Leeds, Brussels, Paris, Orleans, Lisbon, Coimbra, Rome, and Catania), where he discussed scientific questions with other researchers and became acquainted with new research equipment.
Sahama's long-time friend, Dr. Oleg v. Knorring (1915-1994) from the University of Leeds, accompanied him on several expeditions (Fig.1). v. Knorring was born in 1915 in Novgorod, Russia, but moved and settled after the Bolshevik Revolution with his parents in Finland, the home country of his forefathers. He studied geology and mineralogy under Pentti Eskola at the University of Helsinki. At the invitation of W.Q. Kennedy, he moved in 1948 to United Kingdom. He was a 


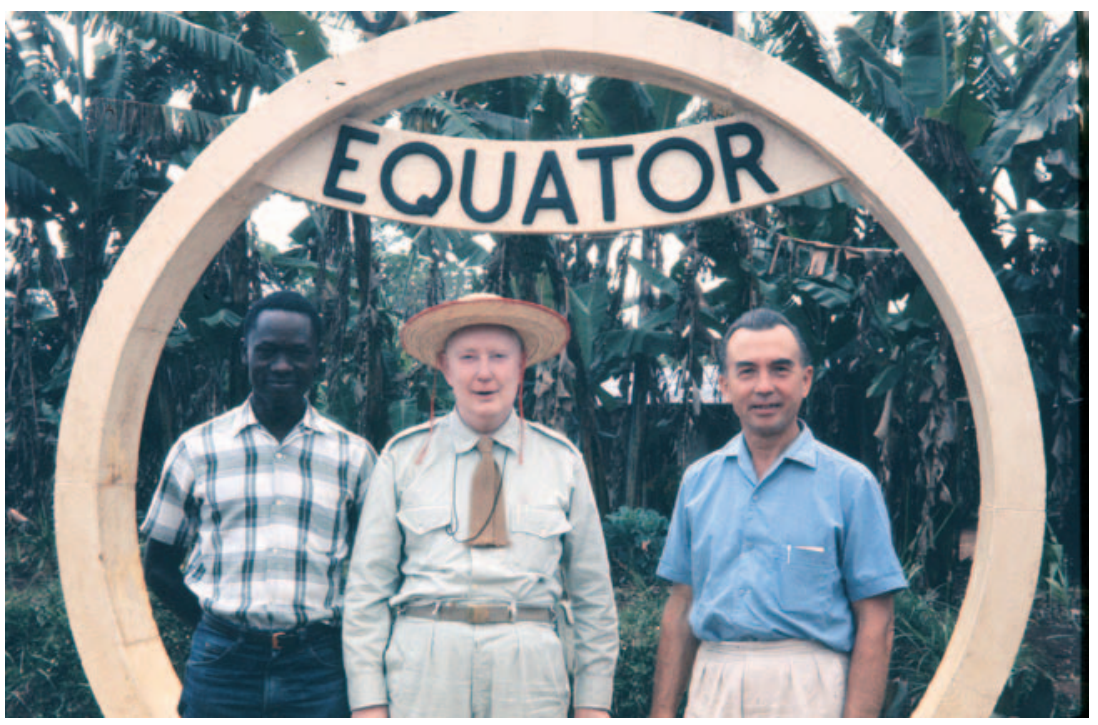

Fig. 1. Tamale Ssali (Geological Survey of Uganda left), Th.G. Sahama and O. v. Knorring on the equator in Uganda. Photo Reijo Alviola in August, 1969.

and tungsten deposits of the same area (Figs. 2-4). In northern Rwanda, their base was in the town of Ruhengeri and they made trips to the pegmatites in the Gatumba area and to the tungsten deposits at Kifurwe (Fig.5), Kabaya and Bugarama.

Sahama and v. Knorring collected mineral samples from various mines and prospects. They also received samples from the offices and owners of the mines. A fruitful collaboration developed between v. Knorring, Sahama, and Sahama's assistants Esko Saari, Martti Lehtinen,

skillful mineralogist and mineral chemist, and had previous experience in studying African pegmatites (Nixon, 1995).

\section{Pegmatites and hydrothermal deposits in Uganda and Rwanda}

\subsection{Pegmatites}

Sahama visited the Buranga pegmatite mine in Rwanda for first time in July 1961 and collected large amount of specimens, especially phosphate minerals. In September 1967, Sahama and O. v. Knorring studied the pegmatites and wolframite occurrences of southwestern Uganda and northern Rwanda, staying several days in G. René's (owner of the Nyanga mine) home in Mutozo, Ankole. Samples were collected from the Nyanga mine (a columbite-tantalite pegmatite), from the Rwanza pegmatite (beryl, columbite, amblygonite, Fe-Mn phosphates), and from the Nyakyshozo pegmatite (beryl, columbite, Fe-Mn phosphates). In addition, they visited the Kirwa tungsten-tin mine and the Bjordal tungsten-bismuth mine near Kisoro. In August-September 1969, Sahama and v. Knorring again examined, during three weeks, the pegmatites
Ragnar Törnroos, and Pentti Rehtijärvi. The normal division of labor was such that $v$. Knorring made the wet-chemical analyses of the minerals, Sahama and his assistants undertook the x-ray crystallographic work and determined the physical and optical parameters, whereas the two senior scientists (ThGS and OvK) usually were responsible for writing the articles.

The Buranga pegmatite in Rwanda has long been known for its rich variety of phosphate minerals (Thoreau \& Bastin, 1954). Gradual deuteric-

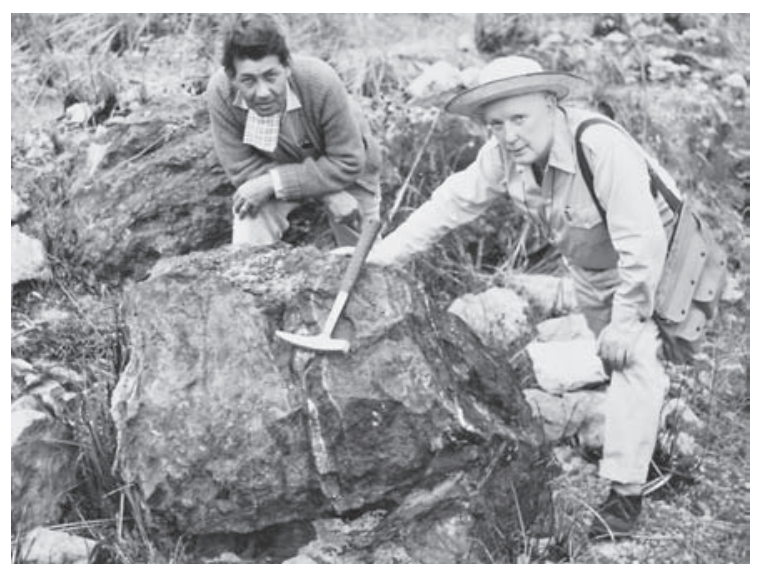

Fig. 2. Th.G. Sahama and G. René at the Kabira columbite-tantalite pegmatite mine in Ankole, southern Uganda. Photo O. v. Knorring in August, 1969. 


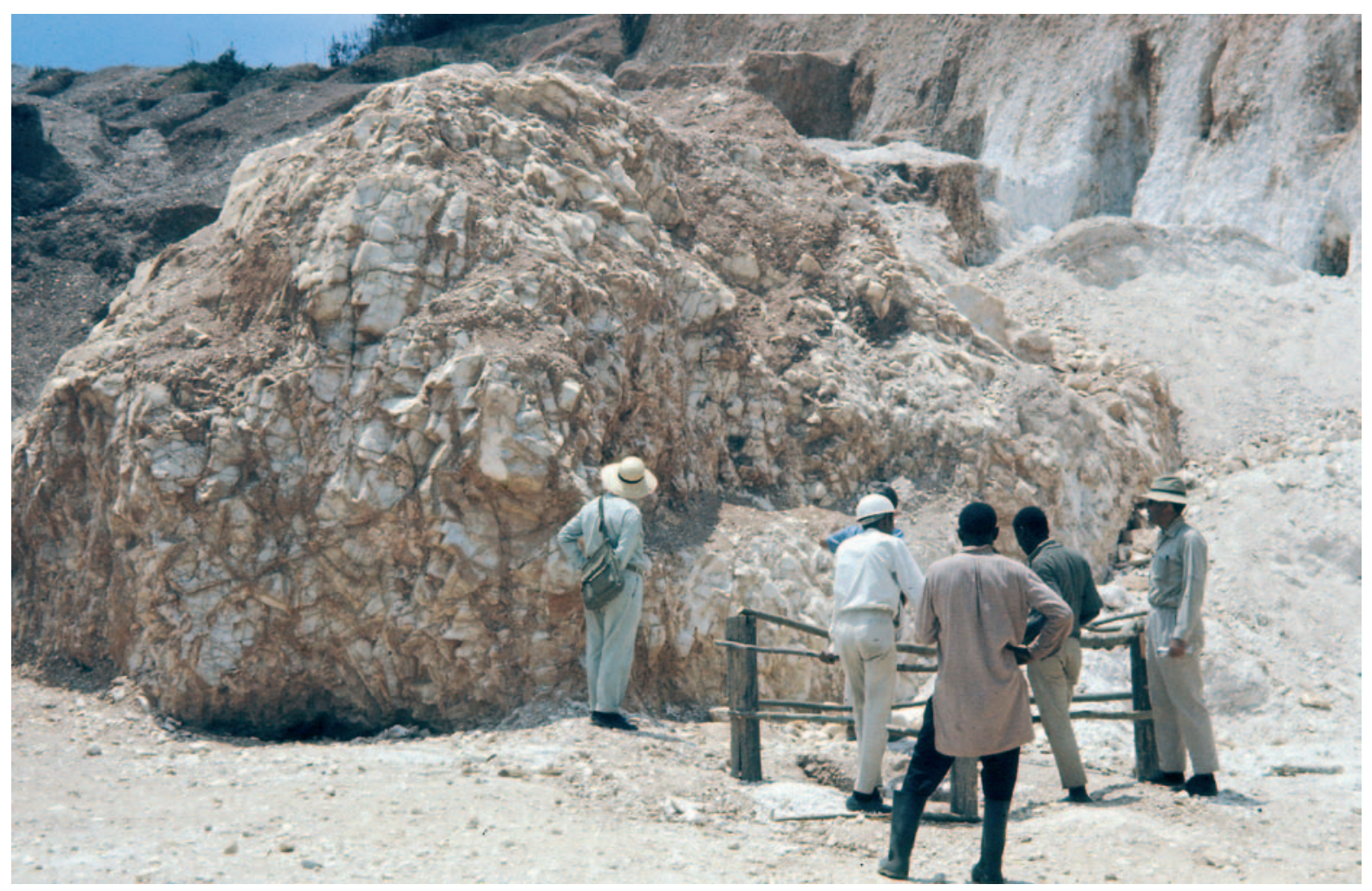

Fig. 3. Th.G. Sahama (on the right) and others on the Mutaka beryl-columbite-cassiterite pegmatite mine in Ankole, southern Uganda. The quartz core of the pegmatite contains large spodumene laths as well as some amblygonite. Photo R. Alviola in August, 1969.

hydrothermal alteration and weathering in the tropical climate have produced a number of secondary phosphate minerals from the primary pegmatite minerals amblygonite-montebrasite and lithiophilite-triphyllite. v. Knorring and coworkers also found new mineral species: bertossaite $(\mathrm{Li}, \mathrm{Na})_{2}\left(\mathrm{Ca}, \mathrm{Fe}^{2+}, \mathrm{Mn}^{2+}\right) \mathrm{Al}_{4}\left(\mathrm{PO}_{4}\right) 4(\mathrm{OH}, \mathrm{F})_{4}$ (v. Knorring \& Mrose, 1966) and gatumbaite $\mathrm{CaAl}_{2}\left(\mathrm{PO}_{4}\right)_{2}(\mathrm{OH})_{2} 2 \mathrm{H}_{2} \mathrm{O}$ (v. Knorring \& Fransolet, 1977). Lehtinen and Sahama participated in the study of a bluish prismatic mineral, which turned out to be a new monoclinic mineral with a formula $(\mathrm{Na}, \mathrm{Ca})\left(\mathrm{Fe}^{2+}, \mathrm{Mg}\right)_{2} \mathrm{Al}_{10}\left(\mathrm{PO}_{4}\right)_{8}(\mathrm{OH}, \mathrm{O})_{12} 4 \mathrm{H}_{2} \mathrm{O}$. The mineral was named burangaite after the site of discovery (v. Knorring et al., 1977; Table 2). Later, v. Knorring \& Sahama (1982) published a detailed mineralogical study, with crystallographic and $x$-ray data and chemical analyses, of strengite, bertrandite, and an unnamed dufrenite-like mineral. A review of the mineralogy of the Buranga pegmatite was published by Daltry \& v. Knorring (1988). The approved mineral species discovered in the Buranga pegmatite totalled 105 items, 55 of them phosphates.

Although Sahama and v. Knorring studied pegmatites in Uganda and collected large amounts of samples, they wrote only a few joint papers about them. At the time of their visits, several of the pegmatites were being mined for beryl, columbite, cassiterite, and amblygonite. During a visit to some of the Ankole pegmatite mines in 1967, Sahama and v. Knorring received from Mr. G. René wodginite crystals from the Nyanga mine for a mineralogical laboratory study. In this mine, columbite aggregates up to $200 \mathrm{~kg}$ in weight had been found in the footwall, between the quartz core and muscoviterich marginal facies. v. Knorring et al. (1969a) published a detailed study of wodginite including a description of its mode of the occurrence, crystal form, twinning, $\mathrm{x}$-ray crystallography (by single crystal and 


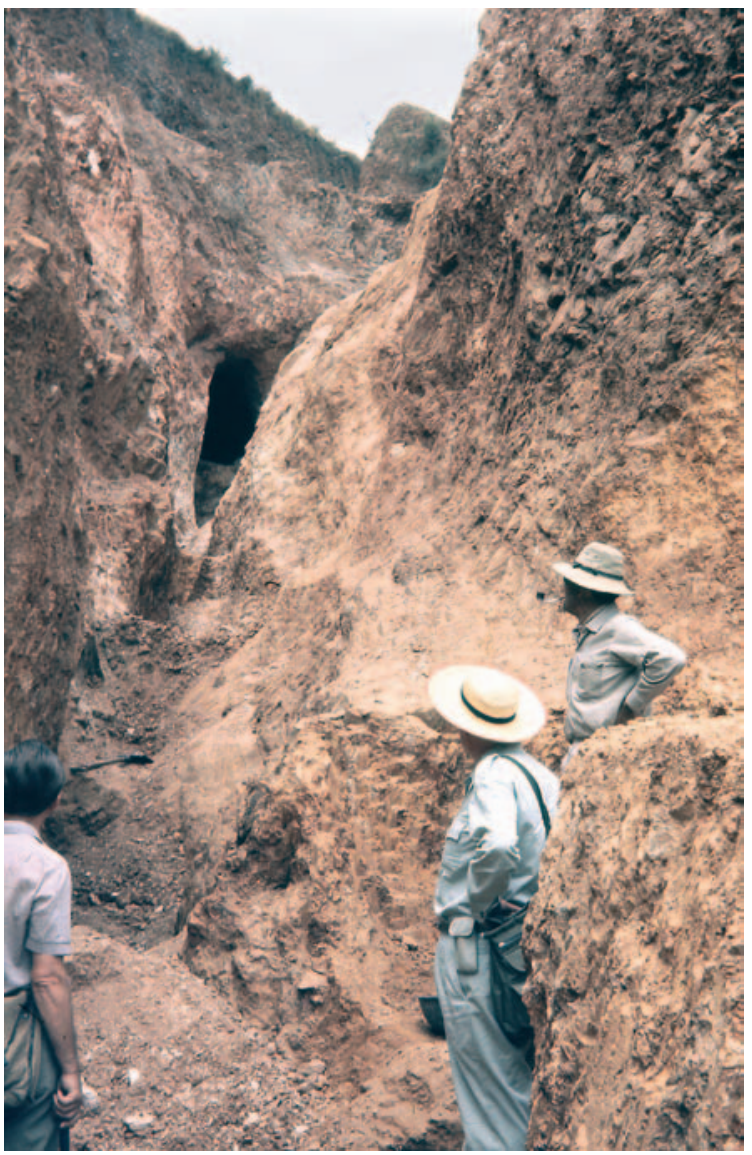

Fig. 4. O. v. Knorring (left), Th.G. Sahama and G. René studying the Mutaka pegmatite in Ankole, Uganda. Photo R. Alviola in August, 1969.

powder data), physical properties, and chemical composition. Ten years later a note was published on rynersonite $\mathrm{Ca}(\mathrm{Ta}, \mathrm{Nb})_{2} \mathrm{O}_{6}$ that occurred with wodginite and microlite in the Wampeno (Gamba Hill) pegmatite in Uganda (v. Knorring \& Sahama, 1979), and another note on zincian staurolite that occurred with bertrandite, crandallite, goyazite, and eosphorite in the Nyanga pegmatite (v. Knorring et al., 1979).

\subsection{Tungsten deposits}

Tungsten and tin were reported from Uganda in 1926, and they were mined there until the 1990's. Numerous deposits occur in the field that extends from south-western Uganda (Kigezi district) to Rwanda and eastern Congo. The ore bodies consist
Table 2. New mineral species found and described by Th.G. Sahama and his coworkers from the African pegmatites and hydrothermal deposits.

Cerotungstite $\mathrm{CeW}_{2} \mathrm{O}_{6}$, monoclinic, Uganda. Named after chemical composition. Sahama, Th.G., v. Knorring, O. \& Lehtinen, M. (1970b)

Mpororoite $\left(\mathrm{Al}, \mathrm{Fe}^{3+}\right)_{2} \mathrm{WO}_{3} 6 \mathrm{H}_{2} \mathrm{O}$, triclinic?, Uganda. Named after the place of discovery. v. Knorring, O., Sahama, Th.G. \& Lehtinen, M. (1972)

Karibibite $\quad \mathrm{Fe}_{2}{ }^{3+} \mathrm{As}_{4}{ }^{3+} \mathrm{O}_{8}(\mathrm{OH})$, orthorhombic, Karibib, Namibia. Named after the place of discovery. v. Knorring, O., Sahama, Th.G. \& Rehtijärvi, P. (1973b)

Hafnon $\quad \mathrm{HfSiO}_{4}$, tetragonal, Zambezia, Mozambique. Named after chemical composition (zircon-hafnon). Correia Neves, J.M., Lopes Nunes, J.E. \& Sahama, Th.G. (1974b)

Burangaite $\quad(\mathrm{Na}, \mathrm{Ca})_{2}\left(\mathrm{Fe}^{2+}, \mathrm{Mg}\right)_{2} \mathrm{Al}_{10}(\mathrm{OH}, \mathrm{O})_{12}\left(\mathrm{PO}_{4}\right)_{8}$ $4 \mathrm{H}_{2} \mathrm{O}$, monoclinic, Rwanda. Named after the place of discovery. v. Knorring, O., Lehtinen, M. \& Sahama, Th.G. (1977)

Namibite $\quad \mathrm{Cu}^{2+}(\mathrm{BiO})_{2} \mathrm{~V}^{5+} \mathrm{O}_{4}(\mathrm{OH})$, monoclinic, Namibia. Named after the Namib Desert. v. Knorring, O. \& Sahama, Th.G. (1981)

Unnamed natural bismuth vanadate $\mathrm{BiVO}_{4}$, monoclinic, Mozambique. v. Knorring, O., Sahama, Th.G., Lehtinen, M., Rehtijärvi, P. \& Siivola, J. (1973). The mineral was named clinobisvanite by Bridge, P. J. \& Pryce, M.W. (1974)

of single mineralized quartz veins, sheeted vein swarms or stockworks. The main tungsten minerals are wolframite (usually the iron end member ferberite) and scheelite. Some cassiterite may occur with the tungsten minerals or, in some instances, separately. The ore bodies occur in mica schists and phyllites or in marginal parts of granitic intrusions.

From Sahama's notebook it appears that Sahama and $\mathrm{v}$. Knorring were interested in both the origin and mineralogy of the tungsten deposits. At that time, there existed two different models of the origin of the central African tungsten deposits: a magmatic-hydrothermal model and an alternative 


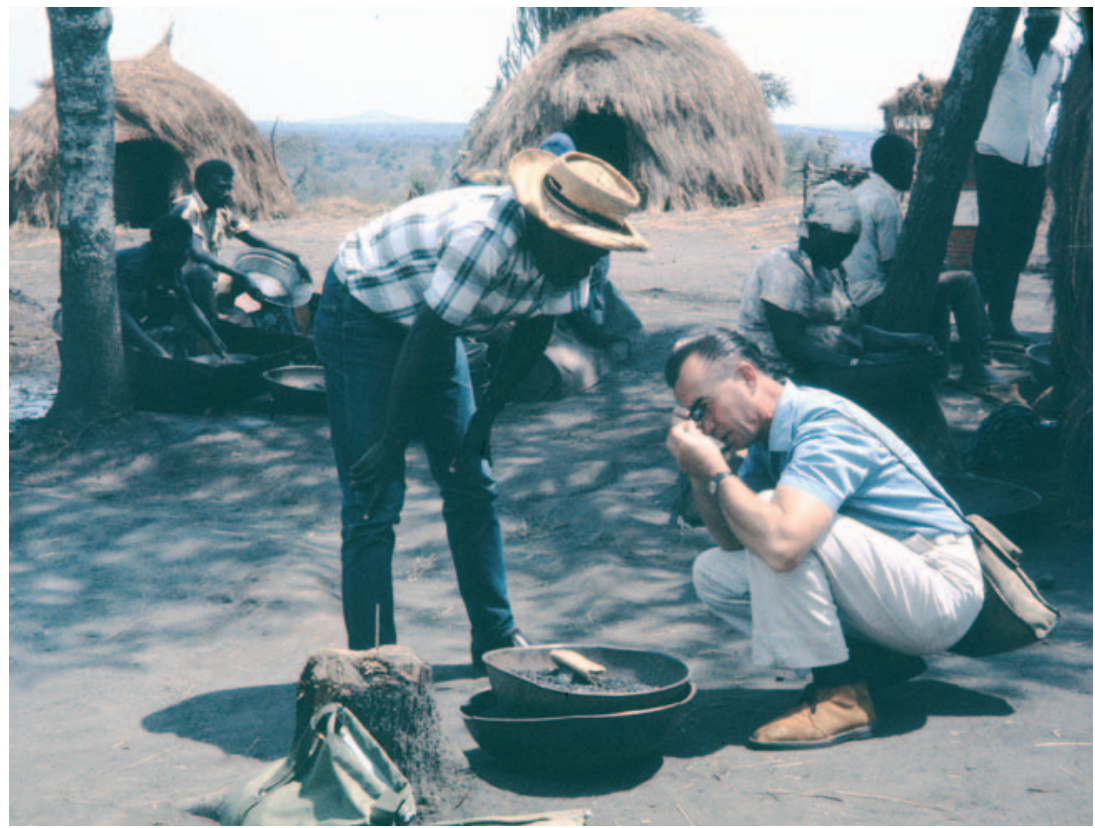

Fig. 5. O. v. Knorring studying under magnifying glass a panned heavy mineral fraction from the Kifurwe tungsten-tin mine in northern Rwanda. Photo R. Alviola in August, 1969. model involving mobilization of syngeneticsedimentary deposits. Sahama's notebook gives the impression that he was leaning towards the latter model, but in their publications Sahama and v. Knorring did not seriously consider this problem. Instead, they concentrated on the mineralogy of tungsten deposits and, especially, on the relationship between primary and secondary tungsten minerals.

Their first step was a study of anthoinite. The mineral was discovered and described by Varlamoff (1947) from a tungsten locality in the Congo, but its crystallographic data were poorly defined. Varlamoff interpreted the mineral to be a pseudomorph after scheelite or wolframite. Later, anthoinite was reported from many other tungsten deposits in central Africa. According to Sahama et al. (1970a), anthoinite is present in most - if not all ferberite deposits of the southern Uganda-Rwanda-Congo tungsten field and is in many instances a pseudomorph after scheelite. The mineral was too fine-grained (grain size $<2 \mu \mathrm{m}$ ) for optical determination and single-crystal $\mathrm{x}$-ray studies. Electron micrographs showed that the mineral has one pronounced cleavage plane. By using scanning electron microscopy, electron diffraction data and the flat layer specimen technique applied in clay mineralogy, Sahama and Lehtinen succeeded in indexing the x-ray powder pattern of anthoinite and calculating the unit cell dimensions. The mineral was triclinic (pseudomonoclinic). A thermobalance run suggested that the mineral contained water as $\mathrm{OH}$ in its structure. Two chemical analyses by v. Knorring corresponded to the formula $\mathrm{AlWO}_{3}(\mathrm{OH})_{3}$.

From the Mpororo tungsten mine in Kigezi, Uganda, v. Knorring et al. (1972) discovered a new secondary tungsten mineral resembling anthoinite. The mineral differed from anthoinite in $\mathrm{x}$-ray powder pattern and had a higher content of water. A wet chemical analysis suggested the formula $(\mathrm{Al}, \mathrm{Fe})_{2} \mathrm{O}_{3}$ $2 \mathrm{WO}_{3} 6 \mathrm{H}_{2} \mathrm{O}$. The mineral was named mpororoite after the place of discovery. Later, Matsubara et al. (1984) described anthoinite and mpororoite from Tasmania and suggested for them the chemical formulae $\mathrm{WAlO}_{3}(\mathrm{OH})_{3}$ and $\mathrm{WAlO}_{3}(\mathrm{OH})_{3} 2 \mathrm{H}_{2} \mathrm{O}$, respectively.

From some tungsten deposits of northern Rwanda and the Kigezi district in southwestern Uganda, Sahama et al. (1970b) described another new mineral, which occurred as radiating bladed crystals in association with anthoinite. Wet chemical and $\mathrm{x}$-ray fluorescence analyses and $\mathrm{x}$-ray diffraction studies (single crystal and powder methods) showed that the mineral is a cerian analogue of yttrotungstite and it was named cerotungstite. The idealized formula for the mineral is (REE) $\mathrm{W}_{2} \mathrm{O}_{6}(\mathrm{OH})_{2}$, Ce being the main rare earth element (REE).

To complete the studies on the secondary tungsten minerals, Sahama (1981) published a comprehensive review of the subject. In that article, he gave a useful description of the mode of occurrence 
and mineralogical data of the secondary tungsten minerals "reinite" (fine-grained variety of ferberite occurring as an alteration product of scheelite), anthoinite, mpororoite, ferritungstite, alumotungstite, hydrotungstite, tungstite, yttrotungstite, and cerotungstite. Except hydrotungstite and yttrotungstite, all these minerals were found in the southwestern Uganda-Rwanda field. The secondary tungsten minerals derive from the primary tungsten minerals scheelite and wolframite (an intermediate member in the hübnerite $\mathrm{MnWO}_{4}$ - ferberite $\mathrm{FeWO}_{4}$ series). Primary wolframite occurs as black crystals of uniform orientation.

\section{Pegmatites of Zambezia, northeastern Mozambique}

\subsection{The expeditions}

The pegmatites of the district of Zambezian in eastern Mozambique provided a most fruitful research topic for Sahama and his collaborators. His six expeditions to Mozambique (1961, 1963, 1966, 1972, 1973, and 1974) produced a huge amount of mineralogical research material and a number of scientific articles. His main co-workers during these expeditions were Professors J.M. Correia Neves and J.E. Lopes Nunes from the University of Lourenço Marques (founded in 1962; since 1975 known as Eduardo Mondlane University) (Fig. 6).

The Alto Ligonha pegmatite field in Zambezia was an important producer of pegmatite minerals (beryl, columbite-tantalite, bismuth, alkali feldspar etc.) in the 1930's to 1970's, but since the 1980's the production has dropped dramatically. When Sahama and his collaborators started their studies in the area, several pa- pers had already been published on the large zoned pegmatites and their minerals (e.g. Hutchison \& Claus, 1956; Cotelo Neiva \& Correia Neves, 1960).

During his first short visit with Dr. O. v. Knorring to Mozambique, Sahama got excited about the pegmatites in the Alto Ligonha District, Zambezia Province. They collected large amount of exquisite specimens, particularly from the Muiane and Morrua pegmatites. Expressions like "We received terrible amounts of exceptional samples" are repeated in Sahama's diaries. The specimens collected included columbite, tantalite, stibiotantalite, Mn-tantalite, bismuth, bismutite, samarskite, euxenite, rutile (?), topaz, pollucite, spodumene, an unknown mineral from Muiane and another from Morrua. Sahama packed specimens in four boxes that he mailed to Finland. In addition, the polite manager of the Muiane mine, Mr. Enrico Lopes da Silva, promised to send to him larger specimens by ship. Sahama was so excited about the Zambezian pegmatites, that after them, even the rocks of the Bushveld layered complex did not attract his attention.

Sahama began his 1963 expedition to Africa with a visit to Portugal. There were two obvious reasons: (1) Mozambigue belonged at that time to Portugal as an overseas province, and Portuguese

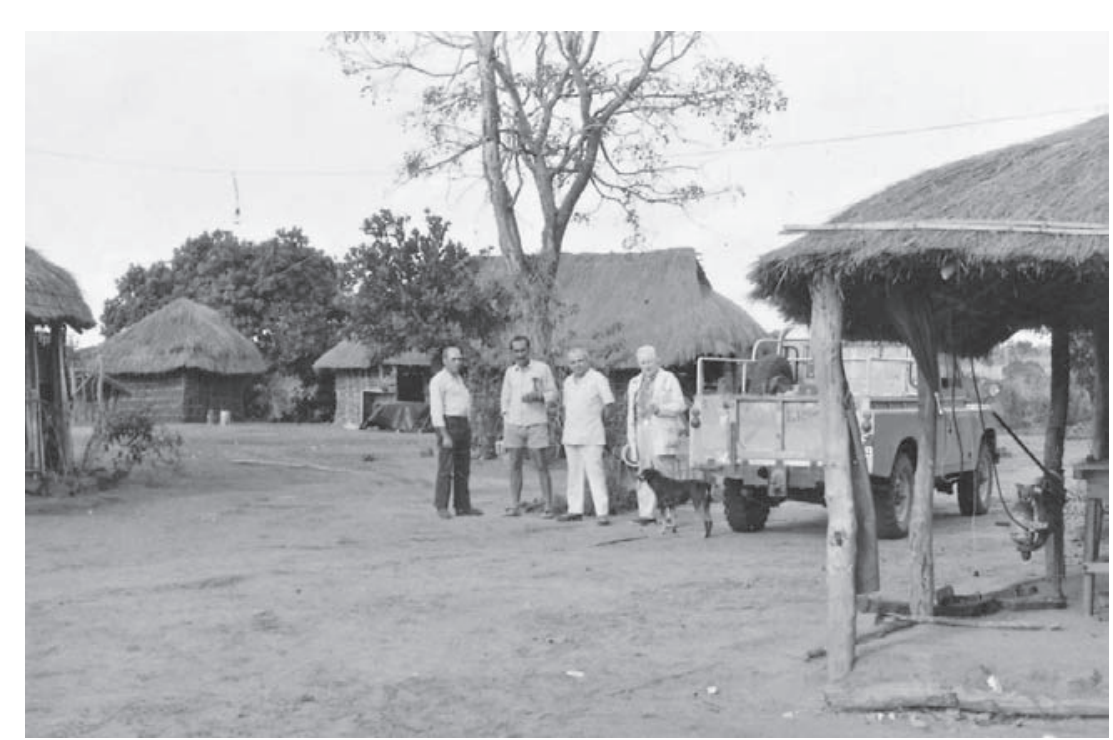

Fig. 6. Pegmatite researchers at the Niane smaragd mine in Zambezia, Mozambique. Th.G. Sahama and J.M. Correia Neves on the right. Photo Jorge Cabral in August, 1973. 
geologists had a traditional way of studying the bedrock and mineral deposits of Mosambique; (2) there were in Portugal several wolframite and cassiterite deposits, in which Sahama was interested. In Lisboa, he visited the University, meeting Professors Cotelo Neiva and Carlos Teixeira, visited the Geological Survey and the Overseas Institute, and made an excursion with Mr. M. Portugal to some wolframite and cassiterite deposits. In Mozambique, he first stayed a few days in Lourenço Marques (when Mozambique became independent in 1975, the city was renamed Maputo) visiting the University, the Geological Survey, and offices of the pegmatite mines. In Zambezia, he spent ten days collecting research material from the pegmatites of Muiane, Murropino, Mujamal, Muhano, Nuaparra, Naquissupa, Nahora, Morrua, Mocuba, Mutala, Conco, and Moneio. Everywhere the mining company staffs were friendly and helpful. Sahama himself collected specimens from the mines and prospects, but, as he said, the best samples came from the offices and collections of the mine owners. $\mathrm{He}$ received samples of $\mathrm{Ta}-\mathrm{Nb}$ minerals, beryl and tourmaline of different colors, bismuth- and antimony-minerals as well as unknown minerals. After the round trip to Zambezia, 12 boxes, together about 50 kilograms, were mailed to Finland. The best specimens Sahama kept packed in different places in his luggage.

In 1966, Sahama was again in Mozambique. At the University of Lourenço Marques, he met Professor Correio Neves, who had in less than three years built a stately geology department. In Zambezia, he was hosted and guided by $\mathrm{Mr}$. Marcellino da Silva Campos and brothers Jorge, Pio and Luis Cabral, all working in the mineral business. In five days, Sahama obtained again about 50 $\mathrm{kg}$ of mineral samples from the pegmatites. In particular, he collected samples of Bi-minerals,"Scbearing columbite" (ixiolite), zoned microlite, and euxenite (?) from the Nauele pegmatite, all suitable for detailed studies.

From Sahama's small address book (1972) and his notebook (1973) it appears that he visited the Zambezian pegmatite field also in August 1972, probably together with v. Knorring, but the present author has not found any further details in Sahama's diaries.

In July-August 1973 Sahama was a guest lecturer and researcher in the University of Lourenço Marques. His lectures dealt with Mt. Nyiragongo lavas, tungsten minerals of central Africa, and pegmatite minerals of Zambezia. He used much of his time studying mineral samples from the Zambezian pegmatites stored in the Department of Geology. He received and "acquired" zircon (and xenotime) samples from different places (Meco, Nauela, Guilherme I, Boa Esperança, Ribue, Rio Maria, Morrua) for hafnium analyses - a collaboration with Correia Neves and Lopes Nunes. He $\mathrm{x}$-rayed his new collection of tantalite and $\mathrm{Bi}$ minerals. A sample from Monapo contained a gray alteration product around a metallic bismuth core, that he identified as sillenite $\mathrm{Bi}_{12} \mathrm{SiO}_{20}$. This mineral was then also identified from other bismuth locations. Sahama also acquired a specimen of ixiolite from Boa Esperança, Ribaué, and monazitexenotime-zircon-tantalite concentrates from the Maria III mine. He intended to study especially the zircon-xenotime intergrowths. Sahama wrote in his notebook: "Because these samples are from J.E. Lopes Nunes' collection, the work must be done together with him." Together with Lopes Nunes and Correia Neves, he tested their idea to estimate from the intensity relations of certain $x$-ray reflections the cesium content of beryl, and took specimens back to Finland to continue his studies in Helsinki.

Again in August 1973, together with Correia Neves and Lopes Nunes, Sahama made 1973 an excursion to Zambezia. The travel from Lourenço Marques to Morrua was made by local airplane, and the field travel by car. In Morrua, they stayed in Pio Cabral's home, and the hostess was Luzia, the sister of the six Cabral brothers (all enthusiastic mineral collectors). From Morrua, they visited the Morrupino pegmatite, where Sahama received bismutite and tantalite, and the Mekla and Maria III emeraldscheelite mines. From the Morrua mine, Sahama found bismutite and precious beryl.

From Morrua, the three professors drove to Jorge Cabral's place. They visited first the Niane emerald mine, situated in an amphibole schist near 
Cabral's house, and then the Nacacan pegmatite that had produced blue beryl. The last visited area was Muiane, 84 km from Jorge Cabral's house. From Muiane, Sahama received bismuth, stibiotantalite, tantalite, ilmenorutile (?), and tourmaline; and from the Nuaperra, pegmatite bismutite and rose quartz.

In June-July 1974, Sahama made his last expedition to Mozambique. The main purpose was now to revise and finish two manuscripts with Lopes Nunes and Correia Neves and to make an excursion to Zambezia. He was accommodated in Casa Universitas, as in 1973.

Soon after his arrival in Lourenço Marques, Sahama delivered to Lopes Nunes and Correia Neves a draft manuscript of the zircon-hafnon series and another one on the bismuth and antimony minerals of the pegmatites of Zambezia. Sahama was informed of two new mineral occurrences: (1) a niobium-rich mineral with rutile structure, found in a carbonatite dike in Bergoza near Tete, and (2) bismutotantalite found in a new locality in Zambezia. Sahama become involved in the study of these minerals.

His last excursion to the pegmatites of Zambezia Sahama made together with Lopes Nunes by Geological Survey's vehicle. The excursion points were largely the same as in 1973 , and so too were the collected minerals. The highlight of the trip was the visit to the Namacotche pegmatite mine, where a zone with large, beautiful morganite (rose beryl) crystals had been discovered. Sahama wrote enthusiastically to his notebook: "Namacotche is the best place to find morganite. Here the mineral does not occur in round pockets, but in a zone that continues down to an unknown depth. Here morganite is, together with quartz and partly weathered cleavelandite, a main constituent of the zone, not just a rare accessory mineral. I could not have dreamed of such a place. Most mineralogists will never see such a place." Sahama collected specimens.

After returning to Lourenço Marques, Sahama concentrated in finalizing the two manuscripts. He received the comments and additions by Lopes Nunes and Correia Neves, and prepared the manuscripts ready for printing. The paper on bismuth and antimony minerals was submitted to the series of Lourenço Marques University, the zircon-hafnon paper to Contributions to Mineralogy and Petrology (Germany).

\subsection{The pegmatite minerals}

The pegmatites of Zambezia provided an inspiring mineralogical research topic for Sahama and his team for over twenty years. The first papers they published dealt with beryllium minerals: a note on euclase from the Muiane pegmatite (v. Knorring et al., 1964), a paper on the location of alkalis in the beryl structure (Vorma et al., 1965), and a study of the polygonal growth structures in beryl (Sahama, 1966). Beryl samples for these studies came mainly from Zambezia.

Tantalum and niobium-bearing minerals were of special interest to Sahama and his team. Nickel et al. (1963a,b) had shown that the already abandoned tin-bearing tantalite mineral ixiolite (or ixionolite) from Kemiö, southwestern Finland (Nordenskiöld, 1858) is, indeed, a true mineral species, a monoclinic substructure of columbite-tantalite, and that the columbite-tantalite has a monoclinic (pseudo-orthorhombic) counterpart, wodginite. All these minerals are chemically and structurally closely related, and their identification requires careful xray crystallographic studies. These findings activated research of iron-manganese-tin-niobium-tantalum oxides. Sahama and v. Knorring collected specimens from African pegmatites, v. Knorring made most of the chemical analyses, whereas the $\mathrm{x}$-ray crystallographic and other physical determinations were made in Sahama's laboratory. A paper on the properties of a nearly pure, red to colorless, manganotantalite $\mathrm{MnTa}_{2} \mathrm{O}_{6}$ (with $\mathrm{Ta} / \mathrm{Nb}=99 / 1$ and $\mathrm{Mn} / \mathrm{Fe}$ = 97/3) was published by v. Knorring et al. (1966). Two years later, a paper appeared on a niobian wolframite, intermediate between wolframite and iron manganese niobate of the type $\mathrm{FeNbO}_{4}$, from the Nuaparra pegmatite in Zambezia (Saari et al., 1968). Single-crystal and powder diffraction studies showed that the systematic extinctions were consistent with the space group of monoclinic wolframite (although the angle $\beta$ was $90^{\circ}$ ), but did not agree 
with the orthorhombic columbite space group.

v. Knorring, Sahama and Lehtinen published a study on scandian ixiolite in 1969 (up to $7.50 \%$ $\mathrm{Sc}_{2} \mathrm{O}_{3}$ ) from some pegmatites from Zambezia and Madagascar (v. Knorring et al. 1969b), a paper on tin-bearing ferroan wodginite from Ankole, Uganda (v. Knorring et al., 1969a), and a study on wodginite from Karibib, Namibia (v. Knorring et al. 1969e). A note on niobian rutile (with $14.6 \%$ $\mathrm{Nb}_{2} \mathrm{O}_{5}$ ) from the Muiane pegmatite, Zambezia, was published by Sahama (1978b).

Sahama finished his studies on the tantalumniobium minerals with a comprehensive study of the orthorhombic tantalite-niobite series (columbite group) minerals from the Zambezian pegmatites (Sahama, 1980). This paper gives chemical, physical and unit cell data of the minerals and presents diagrams showing the dependence of density and unit cell dimensions on the chemical composition in this solid solution series.

Wodginite and ixiolite are nowadays known from various localities around the world, and the knowledge of their crystal structure and chemical composition has increased. Wodginite is regarded as an isostructural mineral group resembling the columbite group, with a general formula $\mathrm{ABC}_{2} \mathrm{O}_{6}$, where $\mathrm{A}=\mathrm{Mn}, \mathrm{Fe}^{2+}$, $\mathrm{Li} ; \mathrm{B}=\mathrm{Sn}^{4+}, \mathrm{Ti}, \mathrm{Fe}^{3+}$; and $\mathrm{C}=$ $\mathrm{Ta}, \mathrm{Nb}$, and a nomenclature based on the $\mathrm{A}-$ and B-cation sites has been developed (Ercit et al., 1992). The studies of Sahama and his coworkers provided important basic material for later interpretations and mineral classifications.

Sahama and his team published several studies on bismuth-antimony minerals. Sahama and Lehtinen (1968) presented a mineralogical description of bismutite, a bismuth carbonate, occurring as "bismuth ocher" together with minor amounts of metallic bismuth in some Zambezian pegmatites. v. Knorring et al. (1973) described two bismuth vanadate minerals from the Mutala pegmatite with the formula $\mathrm{BiVO}_{4}$ : an orthorhombic pucherite and an unknown (new) orthorhombic yellow mineral for which they presented crystallographic data including indexed scanning electron micrographs of crystals, unit cell dimensions and chemical composition. The data matched the properties of a synt- hetic monoclinic bismuth vanadate, and v. Knorring et al. (1973a) described the mineral simply as "natural monoclinic bismuth vanadate". Bridge and Pryce (1974) reported the same new mineral in western Australia and gave it the name clinobisvanite (Table 2).

A comprehensive study of the bismuth and antimony minerals of the Zambezian pegmatites was published by Correia Neves et al. (1974a). Mineralogical data including mode of occurrence, crystal habit, unit cell dimensions, $\mathrm{x}$-ray pattern, chemical composition, and physical and optical properties were presented for native bismuth, bismuth oxide minerals bismite and sillenite, bismutite $\mathrm{Bi}_{2} \mathrm{CO}_{5}$, bismutinite $\mathrm{Bi}_{2} \mathrm{~S}_{3}$, bismoclite $\mathrm{BiOCl}$, bismutotantalite-stibiotantalite, bismuthian microlite, and the bismuth vanadates.

It has long been known that hafnium occurs as a minor constituent in zirconium minerals substituting for zirconium. As a result of reconnaissance geochemical studies of African pegmatites, v. Knorring \& Hornung (1961) observed elevated hafnium contents in zircon from certain lithium-bearing pegmatites rich in tantalum and representing the late phase of pegmatite crystallization. For example, in a lithium pegmatite from Karibib, $\mathrm{Na}-$ mibia, the hafnium content of zircon rose up to 31 $\% \mathrm{Hf}_{2} \mathrm{O}_{3}$. v. Knorring and Hornung concluded that in lithium-bearing pegmatites enriched in tantalum minerals, hafnium concentrations in zircon may well exceed the zirconium levels. Correia Neves, Lopes Nunes and Sahama directed their studies in the early 1970's to the search for high-hafnium members of the zircon-hafnon series in the Zambezian pegmatites. As research material, they used heavy mineral concentrates from the Muiane, Morrua and Conco mines, and as analytical research methods XRF and electron microprobe. Material was geochemically well selected, and the research was successful. By microprobe, they identified two hafnon crystals from the Muiane pegmatite with atomic ratios $100 \mathrm{Hf} /$ ( $\mathrm{Zr}+\mathrm{Hf}) 92.6$ and 97.2 (Correia Neves et al., 1974b). Natural hafnon was thus discovered. In addition, they identified by XRF several zirconian hafnons with $100 \mathrm{Hf} /(\mathrm{Hf}+\mathrm{Zr}$ ) between 50 and 90. The relationships between properties (density 
and unit cell dimensions) and composition of analysed hafnon-zircon samples were shown by diagrams.

Sahama and his team also published studies on cookeite from Muiane (Sahama et al., 1968) and xenotime from Morrua (Sahama et al., 1973b). Törnroos (1982) published a study on metamict zircon from the samples collected by Sahama from the Zambezian pegmatites. The paper on composition and properties of tourmaline (Sahama et al., 1979) was based on samples from Mozambique, Madagascar and Afghanistan.

\section{Minerals from Madagascar}

As part of the 1967 expedition to Africa, Sahama and v. Knorring made an 18-day excursion to Madagascar to visit various points of mineralogical interest. In Antananarivo, they first visited the Geological Survey (BRGM), where they met Mr. J. Kleiber and Dr. Jacob Altmann and made plans for the tours in Madagascar. They also met United Nations' experts Dr. N. Varlamoff and Dr. A.A. Beus. Then Sahama and v. Knorring spent time in six mineral shops in Antanarivo and bought a good number of mineral specimens including grandidierite, kornerupine, rhodizite, and hibonite. They also visited a quartz mine and a baryte-bastnäsite vein near Ambositra. Then they took a flight to Fort Dauphin (Taolagnaro), southern Madagascar, and visited the Itakefan thorianite mine and another mineral shop. After returning to Antanarivo, Sahama sent six boxes of samples to Helsinki by airfreight. He wrote in notebook that he planned to study the minerals grandidierite, kornerupine, rhodizite, befanamite, tapiolite, ferberite, ampangabeite (samarskite), and betafite systematically and in that order from these samples.

Based on chemical and mineralogical-crystallographic studies of the magnesium-aluminium silicate samples collected from Madagascar, v. Knorring, Sahama and Lehtinen published a note on grandidierite $\mathrm{MgAl}_{3}\left(\mathrm{BO}_{3}\right)\left(\mathrm{SiO}_{4}\right) \mathrm{O}_{2}$ from Fort Dauphin (v. Knorring et al., 1969c) and an article on a phlogopite-kornerupine-orthopyroxene-cordierite gneiss from Inanakafy near Betroka (v. Knorring et al., 1969d). The latter article also contained a detailed discussion of the unit cell content of kornerupine $\mathrm{Mg}_{3} \mathrm{Al}_{6}(\mathrm{Si}, \mathrm{Al})_{5} \mathrm{O}_{21}(\mathrm{OH})$. A study of the mineralogy of sapphirine $(\mathrm{Mg}, \mathrm{Al})_{8}(\mathrm{Al}, \mathrm{Si})_{6} \mathrm{O}_{20}$ by Sahama et al. (1974) was also based partly on samples collected from Madagascar. These papers have been widely cited in studies dealing with high-grade metamorphic Al-rich mafic-ultramafic rocks.

\section{Minerals from Namibia}

O. v. Knorring, who had a first-hand knowledge of mineral occurrences in southern Africa, had collected or received in the 1960's and 1970's mineral samples for detailed studies from SouthWest Africa (Namibia). Some of these samples he studied together with Th.G. Sahama and his assistants: wodginite from Karibib (v. Knorring et al., 1969e), nambulite ( $\mathrm{Li}, \mathrm{Na}) \mathrm{Mn}_{4} \mathrm{Si}_{5} \mathrm{O}_{14}(\mathrm{OH})$ from the Tsumeb area (v. Knorring et al., 1978), karibibite $\mathrm{Fe}^{3+}{ }_{2} \mathrm{As}_{4} \mathrm{O}_{8}(\mathrm{OH})$ (a new mineral species, v. Knorring et al., 1973b) and another new mineral species, namibite $\mathrm{CuBi}_{2} \mathrm{VO}_{6}$, from northwestern Namibia (v. Knorring \& Sahama, 1981; Table 2).

\section{Retrospect}

During a long and productive scientific career spanning over 50 years, from 1930 to 1983, Th.G. Sahama made high quality studies in several branches of geosciences, in particular geochemistry, volcanology, and mineralogy. Mineralogical studies had, throughout the decades of his professional life, played a central role in his research. Since his first expedition to the Virunga Volcanic Field in 1952, Sahama's research activities were orientated mainly towards active volcanoes, granitic pegmatites and other mineral occurrences in eastern and southern Africa.

After the petrological and mineralogical studies of the alkaline lavas of Mt. Nyiragongo in the Virunga Volcanic Field, described by Haapala (2011), Sahama and his assistants Esko Saari, Martti Lehtinen, Ragnar Törnroos, and Pentti Rehtijärvi studied, in collaboration with Oleg v. Knorring, the minerals of granitic pegmatites and hydrothermal 
tungsten deposits in eastern and southern Africa. In the study of the pegmatites of Zambezia, Mozambique, Sahama had fruitful collaboration with J.M. Correia Neves and J.E. Lopes Nunes. Detailed mineralogical descriptions with data on the mode of occurrence, unit cell, chemical composition, and physical properties were presented for silicates, phosphates, tantalum, niobium and titanium oxides, as well as bismuth and antimony minerals from pegmatites in Mozambique, Rwanda, Uganda, Namibia, and Madagascar, for primary and secondary tungsten minerals from Rwanda and Uganda, and for magnesium-aluminum silicates from high-grade metamorphic rocks in Madagascar. Altogether, thirteen new mineral species were found and described, six of them from the Nyiragongo lavas. Sahama published also general mineralogical papers on rock-forming minerals (tourmaline, beryl, sapphirine, calcium olivines, pyroxenes, melilite group), based largely on the new data from the African samples. Sahama's studies have made a significant contribution to the mineralogical science in general, and to the mineralogy and petrology of Africa in particular. He has a firm place in the history of African mineralogy and geology.

In several connections, Sahama emphasized the need for the independent nature of pure, scientific mineralogy and geology. In his speech "On the carbonatites of the African continent" at the $75^{\text {th }}$ anniversary of the Geological Society of Finland in 1961 he stated: "We shall not demand of scientific geological research results that tomorrow would benefit practical life, nor restrict it only to handle local questions of this or that country. If we forget this, then we saddle geology with such a ballast that it gets tired and is not able to climb to the top of the mountain, from where wide views would open up." (translated from Sahama, 1961, p. 68). This principle Sahama, indeed, followed in his published studies. Most of his mineralogical publications are pure mineralogical science, even to the extent that the deposit or rock formation where the mineral occurred, was generally only shortly, if at all, described. However, from his diaries, deposited in the Department of Geology, University of Helsinki, it becomes clear that he paid much attention to such practical aspects as the value of metals and minerals, as well as the amount of ore or industrial minerals in the deposit. He was greatly inspired of the idea of J.M. Correia Neves and J.E. Lopes Nunes that the rubidium and cesium contents of beryl could possibly be used as indicators of economic rare element pegmatites, and he wondered if the zirconium fractions separated as impurities from the feldspar concentrates of the Zambezian (Mozambique) pegmatites could be utilized as hafnium ores. Thus, in doing "pure" mineralogical science, he also had in mind practical geological aspects.

In the University of Helsinki, Sahama trained his students and research assistants to be competent mineralogists, often using as teaching materials mineral samples from the African pegmatites and lavas. Following the example of the esteemed Professor, many of his students continued mineralogical research at the Geological Survey of Finland and at universities, pushing the level of mineralogical research in Finland to a high international standard. With the passing of Sahama and his vibrant energy, it has been impossible to keep pace, and mineralogical research activities in Finland have slowly waned. The most impressive part of Sahama's mineral collection is arranged in a special exhibition at the University of Helsinki Museum, whereas the mineral and lava samples as well as Sahama's notebooks and diaries, suitable for further studies, are deposited in the archived collections of the Department of Geology.

\section{Acknowledgements}

I dedicate this article to late Professor Manuel Serrano Pinto (1936-2011), whose plan to edit a contributed book on the History of Geological Research in Africa, including articles on Th.G. Sahama's volcanological and mineralogical studies in Africa, collapsed because of his untimely death.

I am grateful to Professor Th.G. Sahama's former assistants Dr. Kai Hytönen and Dr. Martti Lehtinen as well as to Dr. Peter Bowden, Dr. Hugh O’Brien and Mr. Reijo Alviola, who kindly reviewed the manuscript and made valuable suggestions. Alviola and Lehtinen also helped in finding photos for the article. 


\section{References}

Bridge, P.J. \& Pryce, M.W. 1974. Clinobisvanite, monoclinic BiVO4, a new mineral from Yinnietharra, Western Australia. Mineralogical Magazine 39, 847-849.

Correia Neves, J.M., Lopes Nunes, J.E., Sahama, Th.G., Lehtinen, M. \& v. Knorring, O. 1974a. Bismuth and antimony minerals from the granite pegmatites of northern Mozambique. Revista Ciãncias Geológicas, Universidade de Lourenço Marques 7, Serie A, 1-37.

Correia Neves, J.M., Lopes Nunes, J.E. \& Sahama, Th.G. $1974 \mathrm{~b}$. High hafnium members of the zircon-hafnon series from the granite pegmatites of Zambezia, Mozambique. Contributions to Mineralogy and Petrology 48, 73-80.

Cotelo Neiva, J.M. \& Correia Neves, J.M. 1960. Pegmatites of Alto-Ligonha (Mozambique - Portuguese East Africa). XXI International Geological Congress, Section 17, 3562.

Daltry, V.D.C. \& v. Knorring, O. 1998. Type-mineralogy of Rwanda with particular reference to the Buranga pegmatite. Geologica Belgica 1, 9-15.

Ercit, T.S., Černy, P. \& Hawthorne, F.C. 1992. The wodginite group III. Classification and new Species. Canadian Mineralogist 30, 633-638.

Haapala, I. 2011. Th.G. Sahama’s (1910-1983)volcanological and mineralogical studies in Africa: Part I. Expeditions to the Virunga Volcanic Field and petrological-mineralogical studies on the Nyiragongo volcano. Bulletin of the Geological Society of Finland 83, 41-55.

Hutchison, R.W. \& Claus, R.J. 1956. Pegmatite deposits from Alto Ligonha, Portuguese East Africa. Economic Geology 51, 757-780.

v. Knorring, O. \& Francolet, A.M. 1977. An occurrence of bjarebyite in the Buranga pegmatite, Rwanda. Schweizerische Mineralogische und Petrologische Mitteilungen 55, 9-18.

v. Knorring, O. \& Hornung, G. 1961. Hafnian zircons. Nature 190, 1098-1099.

v. Knorring, O., Lehtinen, M. \& Sahama, Th.G. 1977. Burangaite, a new phosphate mineral from Rwanda. Bulletin of the Geological Society of Finland 49, 33-36.

v. Knorring, O. \& Mrose, M.E. 1966. Bertossaite, $(\mathrm{Li}, \mathrm{Na})_{2}(\mathrm{Ca}$, $\mathrm{Fe}, \mathrm{Mn}) \mathrm{Al}_{4}\left(\mathrm{PO}_{4}\right)_{4}(\mathrm{OH}, \mathrm{F})_{4}$, a new mineral from Rwanda (Africa). Canadian Mineralogist 8, 668.

v. Knorring, O. \& Sahama, Th.G. 1979. A note of rynersonite from Uganda. Schweizerische Mineralogische und Petrologische Mitteilungen 59, 15-18.

v. Knorring, O. \& Sahama; Th.G. 1981. Namibite, a new copper-bismuth-vanadium mineral from Namibia. Schweizerische Mineralogische und Petrologische Mitteilungen 61, 7-12.

v. Knorring, O. \& Sahama, Th.G. 1982. Some FeMn phosphates from the Buranga pegmatite, Rwanda. Schweizerische Mineralogische und Petrologische Mitteilungen 62, 343-
352.

v. Knorring, O., Sahama, Th.G. \& Saari, E. 1964. A note on euclase from Muiane Mine, Alto Ligonha, Mozambique. Bulletin de la Commission géologique de Finlande 215, 143-145.

v. Knorring, O., Sahama, Th.G. \& Saari, E. 1966. A note on the properties of manganotantalite. Bulletin de la Commission géologique de Finlande 222, 47-54.

v. Knorring, O., Sahama, Th.G. \& Lehtinen, M. 1969a. Ferroan wodginite from Ankole, south-west Uganda. Bulletin of the Geological Society of Finland 41, 65-69.

v. Knorring, O., Sahama, Th.G. \& Lehtinen, M. 1969 b. Scandian ixiolite from Mozambique and Madagascar. Bulletin of the Geological Society of Finland 41, 75-77.

v. Knorring, O., Sahama, Th.G. \& Lehtinen, M. 1969c. A note on grandidierite from Fort Dauphin, Madagascar. Bulletin of the Geological Society of Finland 41, 71-74.

v. Knorring, O., Sahama, Th.G. \& Lehtinen, M. 1969d. Kornerupine-bearing gneiss from Inanakafy near Betroka, Madagascar. Bulletin of the Geological Society of Finland $41,79-84$.

v. Knorring, O., Sahama, Th.G. \& Lehtinen, M. 1969e. Wodginite from Karibib, South West Africa. Indian Mineralogist 10 (P.R.J. Naidu Volume), 105-108.

v. Knorring, O., Sahama, Th.G. \& Lehtinen, M. 1972. Mpororoite, a new secondary tungsten mineral from Uganda. Bulletin of the Geological Society of Finland 44, 107110.

v. Knorring, O. , Sahama, Th.G., Lehtinen, M. \& Rehtijärvi, P. 1973a. Natural bismuth vanadate from the Mutala pegmatite area, Mozambique. Contributions to Mineralogy and Petrology 41, 325-331.

v. Knorring, O., Sahama, Th.G. \& Rehtijärvi, P. 1973b. Karibibite, a new FeAs mineral from South West Africa. Lithos 6, 265-272.

v. Knorring, O., Sahama, Th.G. \& Törnroos, R. 1978. Second find of nambulite. Neues Jahrbuch für Mineralogie, Monatshefte 8, 346-348.

v. Knorring, O., Sahama, Th.G. \& Siivola, J. 1979. Zincian staurolite from Uganda. Mineralogical Magazine 43, 446.

Matsubara, S., Kato, A. \& Nagushima, K. 1984. Mpororoite and anthoinite from the Kara Mine, Tasmania. Mineralogical Magazine 48, 397-400.

Nickel, E.H., Rowland, J.F. \& McAdam, R.C. 1963a. Ixiolite - a columbite substructure. American Mineralogist 48, 961-979.

Nickel, E.H., Rowland, J.F. \& McAdam, R.C. 1963b. Wodginite - a new tin-manganese tantalite from Wodgina, Australia, and Bernic Lake, Manitoba. Canadian Mineralogist 7, 390-402.

Nixon, P.H. 1995. Memorial of Oleg von Knorring 1915-1994. American Mineralogist 80, 189-190.

Nordenskiöld, A.E. 1858. Bidrag till Finlands mineralogi. I. Undersökning af tantalit ifrån Skogböle i Kimito och Tam- 
mela. (Ixiolit u. Tantalit). Acta Societatis Scientiarum Fennicae 5, 163-174.

Saari, E., v. Knorring, O. \& Sahama, Th.G. 1968. Niobian wolframite from the Nuaparra pegmatite, Zambezia, Mozambique. Lithos 1, 164-168.

Sahama, Th.G. 1961. Afrikan mantereen karbonatiiteista [On carbonatites of the African continent]. Geologi 13, Helsinki.

Sahama, Th.G. 1966. Polygonal growth of beryl. Bulletin de la Commission géologique de Finlande 222, 31-42.

Sahama, Th.G. 1978b. Niobian rutile from Muiane, Mozambique. Volume Djalma Guimarães, Journal de Mineralogia Recife 7, 115-118.

Sahama, Th.G. 1980. Minerals of the tantalite-niobite series from Mozambique. Bulletin de Minéralogie 103, 190197.

Sahama, Th.G. 1981. The secondary tungsten minerals, a review. Mineralogical Record 12, 81-87.

Sahama, Th.G. \& Lehtinen, M. 1968. Bismutite from the granite pegmatites of Zambezia, Mozambique. Bulletin of the Geological Society of Finland 40, 145-150.

Sahama, Th.G., v. Knorring, O. \& Lehtinen, M. 1968. Cookeite from the Muiane pegmatite, Zambezia, Mozambique. Lithos 1, 12-19.

Sahama, Th.G., v. Knorring, O. \& Lehtinen, M. 1970a. New data on anthoinite. Bulletin of the Geological Society of Finland 42, 95-99.
Sahama, Th.G., v. Knorring, O. \& Lehtinen, M. 1970b. Cerotungstite, a cerian analogue to yttrotungstite, from Uganda. Bulletin of the Geological Society of Finland 42, 223-228.

Sahama, Th.G., v. Knorring, O. \& Rehtijärvi, P. 1973. Xenotime from Morrua, Mozambique. Bulletin of the Geological Society of Finland 45, 67-71.

Sahama, Th.G., v. Knorring, O. \& Törnroos, R. 1979. On tourmaline. Lithos 12, 109-114.

Sahama, Th.G., Lehinen, M., Rehtijärvi, P. \& v. Knorring, O. 1974. Properties of sapphirine. Annales Academiae Scientiarum Fennicae, Series A III 114, 1-24.

Thoreau, J. \& Bastin, G. 1954, Les phosphates des pegmatites du Ruanda occidenta. Bulletin Académie Royale des Sciencas colonials 25, (5), 1595-1603.

Törnroos, R. 1982. Composition of metamict zircon from Mozambique. Bulletin of the Geological Society of Finland 54, 77-83.

Varlamoff, N. 1947. Anthoinite, noveau tungstate hydrate d'alumine. Annalesde la Société géologique de Belgique 70, B153-B166.

Vorma, A., Sahama, Th.G. \& Haapala, I. 1965. Alkali position in the beryl structure. Bulletin de la Commission géologique de Finlande 218, 119-129. 